\title{
VALUE BASED DAN MARKET BASED SEBAGAI PREDIKTOR HARGA SAHAM PADA PERUSAHAAN LQ45
}

\author{
Arna Suryani \\ Fakultas Ekonomi Universitas Jambi \\ Jl. Lintas Jambi - Muara Bulian KM 15 Mendalo Darat Kota Jambi
}

\begin{abstract}
This study aims to obtain empirical evidence whether value added and market value is predictor of stock prices. The value based concepts is measured by economic value added and market based concepts measured by market value added. The object of study is index LQ45 companies listed in Indonesian Stock Exchange period 2012-2016. The selection of samples based on purposive sampling with certain criteria and selected as many as 18 companies index LQ45. The data used in this research is secondary data using quantitative approach. Further testing will be done by classical assumptions against the data collected using regression analysis and test hypothesis $F$ and $t$.

The results of this study prove empirically that together Economic Value Added and Market Value Added is positive and significant predictor of the company's stock price because the significant is 0.000 smaller than 0.05. Partially significant level of $0.05 \mathrm{EVA}$ has a negative effect of 0.14 on stock prices, it can be concluded that the EVA is a predictor variable has a negative effect that is not significant to stock prices at index LQ45. Significant level of MVA that is equal to 0.000 smaller than the significant level of 0.05. MVA positive influence of 0.599 to stock price. It can be concluded that the partial variable MVA positive effect is a significant predictor variable to stock prices at index LQ45.
\end{abstract}

Keyword: economic value added, market value added, financial performance, stock price

\section{PENDAHULUAN}

Laporan Keuangan merupakan hasil dari proses akuntansi keuangan dan disajikan untuk pihak external perusahaan. Laporan tersebut pada dasarnya berisi mengenai posisi keuangan dan hasil-hasil yang diperoleh perusahaan secara keseluruhan. Dari laporan keuangan tersebut,investor dapat mengetahui informasi internal mengenai kinerja keuangan perusahaan yang merupakan salah satu faktor yang dilihat oleh investor untuk menentukan pilihan dalam membeli saham.

Kinerja perusahaan akan dipantau investor yang telah menanamkan modalnya ke perusahaan tersebut dan juga calon-calon investor yang akan menanamkan modalnya (Burhan, 2013). Pengukuran kinerja yang berbasis pada nilai tambah (value added) diharapkan dapat menghasilkan pengukuran kinerja perusahaan yang realistis dan mendukung penyajian laporan keuangan, sehingga para pemakai laporan keuangan dapat dengan mudah mengambil keputusan baik untuk berinvestasi maupun untuk perencanaan peningkatan kinerja perusahaan.

Konsep pengukuran kinerja berbasis nilai tambah yang dimaksud adalah Economic Value Added (EVA) dan Market Value Added (MVA). EVA sebagai suatu pengukuran kinerja keuangan yang mengombinasikan konsep pendapatan residu. EVAyang positif berarti perusahaan memperoleh laba karena tingkat pengembalian (Return to Total Capital) yang melebihi biaya modalnya (Cost Of Capital), hal ini berarti bahwa perusahaan mampu menciptakan nilai tambah bagi pemilik perusahaan berupa tambahan kekayaan, sedangkan EVA yang negatif berarti total biaya modal perusahaan lebih besar dari pada laba operasi setelah pajak yang

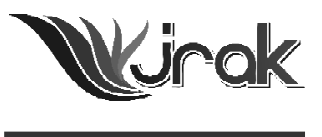

Jurnal Reviu Akuntansi dan Keuangan ISSN: 2088-0685 Vol. 7 No. 1, April 2017 Pp 977-982 
Value Based dan Market Based... diperolehnya, sehingga kinerja keuangan perusahaan tersebut kurang baik. Sedangkan konsepMarket Value Added (MVA) adalah perbedaan antara nilai pasar saham perusahaan dengan jumlah ekuitas modal investor yang telah diberikan. MVA merupakan indikator eksternal yang dapat mengukur seberapa besar kekayaan perusahaan yang telah diciptakan untuk investornya atau MVA menyatakan seberapa besar kemakmuran yang telah dicapai oleh suatu perusahaan untuk mendukung nilai tambah.

Nilai pasar mencerminkan keputusan pasar mengenai bagaimana manajer yang sukses telah menginvestasikan modal yang sudah dipercayakan kepadanya, dalam mengubahnya menjadi lebih besar. Semakin besar MVA, maka semakin baik nilai pasar perusahaan dalam menciptakan kekayaan pemilik modal. MVA negatif berarti nilai dari investasi yang dijalankan manajemen kurang dari modal yang diserahkan kepada perusahaan oleh pasar modal yang berarti kekayaan telah dimusnahkan.

Penelitian yang dilakukan Isa dan Lo (2001) mengidentifikasikan bahwa EVA positif sebagai pencipta nilai perusahaan dan EVA negatif adalah perusak nilai, dan menyimpulkan bahwa EVA positif memiliki korelasi yang lebih tinggi dengan MVA ketimbang EVA negatif. Penelitian yang dilakukan Ury (2013) menjelaskan pengaruh EVA dan MVA terhadap tingkat pengembalian saham pada perusahaan indeks LQ 45 tahun 2009-2011 menunjukkan bahwa EVA dapat menjelaskan variabel tingkat pengembalian saham walaupun dalam porsi sangat kecil dan terbatas. Arif dkk (2013) membuktikan bahwa secara empiris MVA berpengaruh signifikan terhadap tingkat pengembalian saham sektor pertanian. Berdasarkan uraian di atas dapat dikatakan bahwa EVA dan MVA merupakan indikator prediktor dalam usaha perusahaan untuk memaksimalkan nilai perusahaan yang tercermin dalam harga saham. Harga saham merupakan ukuran indeks prestasi perusahaan yaitu seberapa jauh manajemen telah berhasil mengelola perusahaan, dengan demikian harga saham di pasar modal merupakan indikator nilai perusahaan. Melalui Perhitungan EVA dan MVA dapat memberikan bayangan bagi perusahaan terkait dengan peningkatan maupun penurunan nilai laba ekonomis serta nilai tambah pasar sebenarnya yang terwujud dari kinerja perusahaan.Berdasarkan isu penelitian di atas maka perlu diteliti secara empiris guna melihat sebarapa besar pengaruh EVA dan MVA dalam memprediksi nilai dan harga saham perusahaan indek LQ 45 yang terdaftar di Bursa Efek Indonesia periode 2012-2016. Penelitian ini bertujuan untuk mendapatkan bukti empris bahwa: Economic Value Based (EVA) dan Market Value Based (MVA) merupakan predictor dari harga saham, Economic Value Based (EVA) merupakan prediktor dari harga saham, Market Value Based (MVA) merupakan prediktor dari harga saham.

\section{Kerangka Pemikiran}

Kinerja keuangan yang diwakili oleh EVA dan MVA yang baik akan direspon positif oleh investor. Respon positif ini ditunjukkan dengan meningkatnya permintaan saham perusahaan. Apabila permintaan saham meningkat, maka investor yang telah memiliki saham tersebut juga enggan menjual (karena kinerja perusahaan baik) maka harga saham akan meningkat. Meningkatnya harga perusahaan akan meningkatkan nilai perusahaan. Dari penjerlasan tersebut maka peneliti merumuskan hipotesis sebagai berikut:

$\mathrm{H}_{1}$ : Economic Value Added dan/atau Market Value Added merupakan prediktor dari harga saham perusahaan.

$\mathrm{H}_{2}$ : Economic Value Added merupakan prediktor yang signifikan terhadap harga saham perusahaan.

$\mathrm{H}_{3}$ : Market Value Added merupakan prediktor yang signifikan terhadap harga saham perusahaan. 


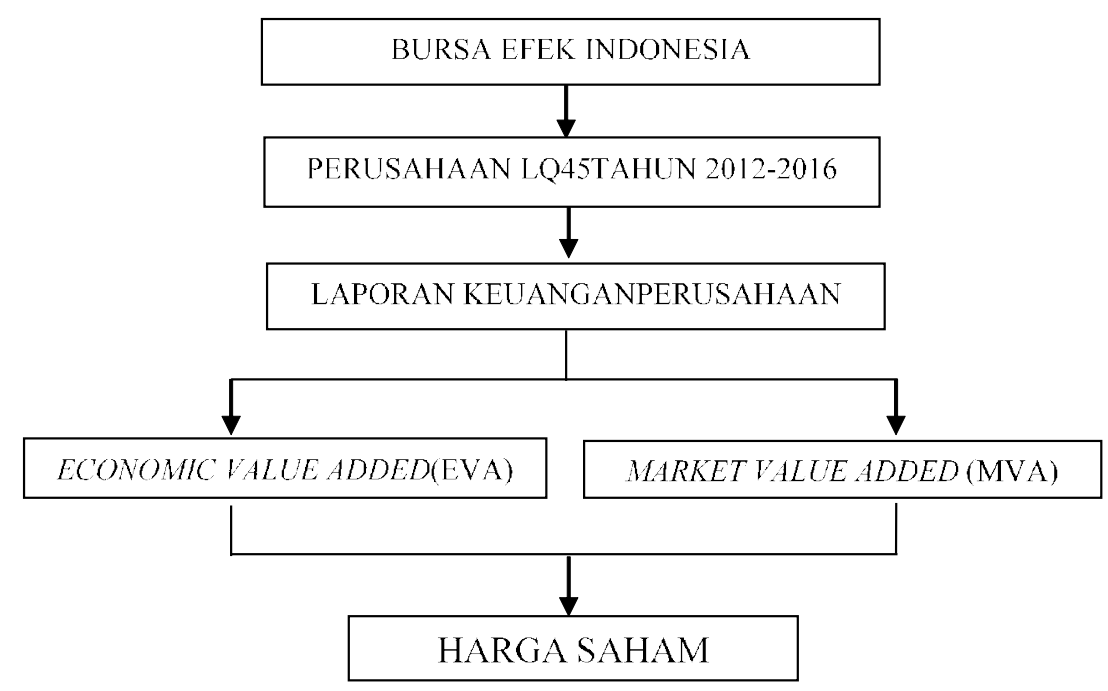

Gambar 1.

Bagan Kerangka

Pemikiran

\section{METODE PENELITIAN}

Objek penelitian ini adalah perusahaan indeks LQ45 di Bursa Efek Indonesia (BEI) yang menerbitkan laporan keuangan tahunan auditor tahun 2012 2016. Penelitian ini menggunakan pendekatan kuantitatif dan jenis data yang digunakan adalah data sekunder. Pemilihan sampel dilakukan dengan menggunakan metode purposive sampling dengan beberapa kriteria tertentu. Sampel yang dipilih sebanyak 18 perusahaan yang konsisten tergabung dalam indek LQ45 selama lima tahun berturut-turut, yaitu Astra Agro Lestari Tbk, Adaro Energy Tbk, Bank Central Asia Tbk, Bank Mandiri (Persero) Tbk, Charoen Pokphand Indonesia Tbk, Gudang Garam Tbk, Indofood Sukses Makmur Tbk, Indocement Tunggal Prakasa Tbk, Jasa Marga (Persero) Tbk, Kalbe Farma Tbk, Lippo Karawaci Tbk, PP London Sumatera Tbk, Perusahaan Gas NegaraTbk, Tambang Batu Bara Bukit Asam Tbk, Semem Indonesia (Persero) Tbk, Telekomunikasi Indonesia (Persero) Tbk, United Tractors Tbk, Unilever Indonesia Tbk.

Model analisis yang digunakan dalam penelitian ini adalah Analisis linear berganda,dengan model $: \mathrm{Y}=\mathrm{a}+\mathrm{b}_{1} \mathrm{X}_{1}+\mathrm{b}_{2} \mathrm{X}_{2}+\mathrm{e}$, dimana: $\mathrm{Y}=$ HargaSaham, $\mathrm{A}=$ Konstanta, $\mathrm{b}_{1} \mathrm{~b}_{2}=$ KoefisienVariabel $\mathrm{X}_{1} \mathrm{X}_{2}, \mathrm{X}_{1}=$ Economic Value Added (EVA), $\mathrm{X}_{2}=$ Market Value Added (MVA), dan e= error.

Dilakukan UjiAsumsi Klasik yaitu:UjiNormalitas, UjiMultikolinieritas, Uji Heteroskedastisitas, dan Uji Autokorelasi serta dilakukan uji hipotesis F dan t dengan tingkat signifikan 95\% atau a $=0.05(5 \%)$. Operasional Variabel yang digunakan adalah sebagai berikut:

\begin{tabular}{|c|c|c|c|c|}
\hline Variabel & Definisi & Rumus & Satuan & Skala \\
\hline $\begin{array}{l}\text { (X1) } \\
\text { Economic } \\
\text { Value Added } \\
\text { (EVA) }\end{array}$ & $\begin{array}{l}\text { EVA adalah indikator internal } \\
\text { yang mengukur kekayaan pe- } \\
\text { megang saham suatu perusa- } \\
\text { haan dalam jangka waktu ter- } \\
\text { tentu (Wijaya dan Tjun } 2009 \text { ). }\end{array}$ & $\begin{array}{l}\text { NOPAT- } \\
\text { Capital } \\
\text { Charge }\end{array}$ & $\mathrm{Rp}$ & Rasio \\
\hline $\begin{array}{l}\text { (X2) } \\
\text { Market Value } \\
\text { Added (MVA) }\end{array}$ & $\begin{array}{l}\text { MVA merupakan suatu peng- } \\
\text { ukur kinerja yang tepat untuk } \\
\text { menilai sukses atau tidaknya } \\
\text { perusahaan dalam mencipta- } \\
\text { kan kekayaan bagi pemiliknya } \\
\text { investor (Steward 2007). }\end{array}$ & $\begin{array}{l}\text { (Jumlah } \\
\text { Saham } \\
\text { Beredar x } \\
\text { Harga } \\
\text { Saham)- } \\
\text { Ekuitas } \\
\end{array}$ & $\mathrm{Rp}$ & Rasio \\
\hline $\begin{array}{l}(\mathrm{Y}) \\
\text { Harga Saham }\end{array}$ & $\begin{array}{l}\text { Harga saham dibentuk karena } \\
\text { ada permintaandan penawaran } \\
\text { atas saham, (Darmadji dan } \\
\text { Fakhruddin 2001:10). }\end{array}$ & Close Price & $\mathrm{Rp}$ & Rasio \\
\hline
\end{tabular}

Tabel 1.

Operasional Variabel 
Value Based dan Market Based...

980
Tabel 2 . Hasil Analisis Uji F

\section{HASIL PENELITIAN}

Berdasarkan uji asumsi klasik diperoleh data berdistribusi normal, tidak terjadi mulikolinieritas, tidak terjadi heteroskedastisitas dan tidak terjadi autokorelasi. Berdasarkan hasil semua pengujian asumsi klasik di atas, maka dapat disimpulkan bahwa semua uji asumsi klasik telah terpenuhi, sehingga model regresi dapat digunakan untuk menganalisis data. Hasil regresi berganda diperoleh:Y= -2.617 014EVA + 599MVA + e. Koefisien regresi untuk EVA yaitu sebesar -014. Koefisien bernilai negatif artinya terjadi hubungan negatif antara EVA terhadap harga saham jika nilai EVA naik maka harga saham akan turun.Koefisien regresi untuk MVA yaitu sebesar 599, Koefisien bernilai positif artinya terjadi hubungan yang positif antara MVA terhadap Harga Saham, semakin naik MVA maka semakin meningkat harga saham.

\section{Pengujian Hipotesis pertama}

$\mathrm{H}_{1}$ : Economic Value Added danMarket Value Added merupakan prediktor dari harga saham perusahaan.

ANOVA $^{a}$

\begin{tabular}{|c|c|c|c|c|c|c|}
\hline & Model & $\begin{array}{l}\text { Sum of } \\
\text { Squares }\end{array}$ & Df & $\begin{array}{c}\text { Mean } \\
\text { Square }\end{array}$ & $\mathrm{F}$ & Sig. \\
\hline \multirow{3}{*}{1} & Regression & 5.467 & 2 & \multirow{3}{*}{$\begin{array}{r}2.734 \\
.202\end{array}$} & \multirow{3}{*}{$\begin{array}{r}13.55 \\
7\end{array}$} & \multirow[t]{3}{*}{$.000^{1}$} \\
\hline & Residual & 17.542 & 87 & & & \\
\hline & Total & 23.009 & 89 & & & \\
\hline
\end{tabular}

a. Dependent Variable: Harga Saham

b. Predictors: (Constant), MVA, EVA

Pada Tabel 2. diatas dapat dilihat bahwa Economic Value Added danMarket Value Added mempunyai tingkat signifikansi sebesar 0,000. Hal ini berarti variabel Economic Value Added danMarket Value Added merupakan prediktor yang positif dan signifikan dari harga saham perusahaan karena angka probabilitas/ signifikansi tersebut $(0,000)$ lebih kecil daripada 0,05. Jadi dapat disimpulkan $\mathrm{H}_{1}$ (hipotesis pertama) tidak dapat ditolak, yang berarti bahwa hipotesis pertama terbukti yang menyatakan bahwa EVA dan MVA merupakan prediktor dari harga saham sehingga $\mathrm{H}_{1}$ diterima.

\section{Pengujian hipotesis kedua}

$\mathrm{H}_{2}$ : Economic Value Added merupakan prediktor yang signifikan terhadap harga saham perusahaan.

Hasil perhitungan Uji t dalam penelitian ini dapat dilihat pada tabel berikut:

\section{Coefficientsa $^{a}$}

\begin{tabular}{|l|c|c|c|c|c|}
\hline \multirow{2}{*}{ Model } & \multicolumn{2}{|c|}{ Unstandardized Coefficients } & $\begin{array}{c}\text { Standardized } \\
\text { Coefficients }\end{array}$ & \multirow{2}{*}{$\mathrm{t}$} & \multirow{2}{*}{ Sig. } \\
\cline { 2 - 4 } & $\mathrm{B}$ & Std. Error & Beta & & \\
\hline (Constant) & -2.617 & 1.282 & & -2.041 & .044 \\
1 EVA & -.014 & .034 & -.038 & -.403 & .688 \\
MVA & .599 & .116 & .485 & 5.178 & .000 \\
\hline
\end{tabular}

Berdasarkan hasil Uji t pada Tabel 3.di atas tingkat signifikanvariabel EVA yaitu sebesar 0,688 lebih besar dari tingkat signifikan 0,05. Maka dapat disimpulkan bahwa secara parsialvariabel EVAmerupakan variabel prediktor yang tidak signifikan terhadap harga saham pada perusahaan indeks LQ45. Dalam hal ini, 
tidak signifikannya pengaruh EVA terhadap harga saham kemungkinan disebabkan oleh berbagai faktor, antara lain kondisi sosial, serta ekonomi indonesia yang tidak stabil sehingga mengakibatkan tingginya resiko bisnis serta ketidakpastian tingkat pendapatan yang akan diterima oleh investor. Tujuan investor menanamkan dananya di pasar modal adalah untuk memperoleh keuntungan semaksimal mungkin. Keuntungan yang diperoleh investor atas dana yang diinvestasikan pada saham biasanya berupa selisih harga untuk memperoleh capital gain pada perusahaan yang memiliki kinerja yang buruk, beberapa investor akan melakukan pembelian saham perusahaan tersebut secara besar-besaran yang nantinya dapat mendorong investor lain untuk membeli saham perusahaan tersebut. Hal inilah yang nantinya akan direspon dengan meningkatnya harga saham perusahaan.

\section{Pengujian Hipotesis ketiga}

$\mathrm{H}_{3}$ : Market Value Added merupakan prediktor yang signifikan terhadap harga saham perusahaan.

Berdasarkan Tabel 3.di atas, tingkat signifikanvariabel MVA yaitu sebesar 0,000 lebih kecil dari tingkat signifikan 0,05 $(0,000<0,05)$. Maka dapat disimpulkan bahwa secara parsialvariabelMVA berpengaruh positifmerupakan variabel prediktor yang signifikan terhadap harga saham pada perusahaan indeks LQ45.

Dalam hal ini, terjadinya pengaruh yang positif dan signifikan antara MVA terhadap harga saham berarti terjadi nilai tambah bagi perusahaan, dan biasanya akan direspon oleh meningkatnya harga saham perusahaan yang memiliki arti bahwa perusahaan berhasil menciptakan nilai tambah perusahaan bagi investor. Semakin besar MVA maka menunjukan nilai tambah yang lebih besar bagi investor, sehingga harga saham juga akan meningkat. Sebaliknya jika MVA negatif berarti perusahaan mengalami penurunan kinerja yang biasanya akan direspon dengan penurunan harga saham.

Pada Uji Determinasi $\left(\mathrm{R}^{2}\right)$ diperoleh nilai R Square yaitu sebesar 0,238. Hal ini menunjukkan bahwa besar pengaruh EVA dan MVA terhadap harga saham adalah hanya sebesar $23,8 \%$ sedangkan sisanya adalah $71,7 \%$ dipengaruhi oleh faktor lain diluar penelitian ini. Hasil koefisien determinasi $\left(\mathrm{R}^{2}\right)$ yaitu sebagai berikut:

\begin{tabular}{|c|c|c|c|c|}
\hline Model & $\mathrm{R}$ & $\mathrm{R}$ Square & Adjusted R Square & Std. Error of the Estimate \\
\hline 1 & $.487^{\mathrm{a}}$ & .238 & .220 & .44903 \\
\hline
\end{tabular}

Predictors: (Constant), MVA, EVA

Dependent Variable: Harga Saham

\section{SIMPULAN}

Penelitian ini bertujuan untuk mendapatkan bukti empirisbahwa Economic Value Based (EVA) dan Market Value Based (MVA) merupakan prediktor dari harga saham dan dirumuskan dalam bentuk tiga hipotesis penelitian. Berdasarkan hasil analisis dan pembahasan ketiga hipotesis tersebut telah terbukti secara empiris, sehingga dapat disimpulkan sebagai berikut: Secara bersama-sama EconomicValue Based (EVA) dan Market Value Based (MVA)merupakan prediktor yang positif dan signifikan dari harga saham indeks LQ45. Economic Value Based(EVA) secara parsial berpengaruh negatif sebesar 0,14 dengan tingkat signifikan sebesar 0,688, dan dapat disimpulkan bahwa Economic Value Based (EVA) merupakan variabel prediktor yang berpengaruh negatif dan tidak signifikan terhadap harga saham pada perusahaan indeks LQ45. Market Value Based (MVA) merupakan variabel predictor yang berpengaruh positif dan signifikan terhadap harga saham pada
Tabel 4.

Uji Determinasi 
Value Based dan Market Based...

982 perusahaan indek LQ45. Hal ini dibuktikan dengan pengaruh Market Value Based (MVA)secara parsial terhadap harga saham sebesar 0,599 dengan tingkat signifikan 0,000 .

Penelitian ini dilakukan hanya terhadap saham-saham yang telah go public terdaftar di Bursa Efek Indonesia hanya di indeks LQ 45. Dengan demikian, generalisasi hasil penelitian ini hanya dapat diterapkan pada populasi indeks LQ45. Model penelitian ini hanya mencakup dua variabel independen dan satu variabel dependen. Untuk penelitian yang akan datang, variabel lain perlu disertakan sehingga dapat dihasilkan model yang lebih komprehensif.

\section{DAFTAR PUSTAKA}

Abdul Halim \& Bambang, Supomo. 2011. Akuntansi Manajemen. Edisi kedua. BPFE. Yogyakarta.

Arif, Kurdiadi,. dkk (2013). "Kinerja keuangan berbasis penciptaan nilai, factor makro ekonomi dan pengaruhnya terhadap return saham sector pertanian". Jurnal akuntansin dan keuangan. 15 (2) 63-74.

Brigham dan Houston. 2006. Dasar-dasar Manajemen Keuanagnan. Salemba Empat. Jakarta.

Chen, S., \& Dodd, J.L. (1997). "EVA: A new panacea?". Journal of Managerial Issue. 9(3), 318-333.

Isa M, Lo W (2001). "Economic value-added in the Malaysia listed companies: A preliminary evidence. Capital Mark". Rev., 9 (1\&2), 83.

Jogianto. (2003). Teori portofolio dan analisis inverstasi. BPFE. Yogyakarta.

Mulyana, D. (2011). "Analisis Likuiditas saham serta pengaruhnya terhadap harga saham pada perusahaan yang berada pada indeks LQ 45 di Bursa Efek Indonesia”. Jurnal magister manajemen. 4(1).

Munawir. 2012. Analisis Informasi Keuangan. Liberty. Yogykarta.

Rashiwala, K. 2003. "Properti assets bring nothing but pain: Real estate firms failing to create shareholder wealth". The Business Times Online Edition. Retrieved April 30, 2003.

Ury, T.R. (2013). "Pengaruh economic value added dan market value added terhadap return saham". Jurnal Ekonmi manajemen Ekonomi. 2 (1).

Young, S. David dan Stephen F. O'Byrne. 2001. EVA dan Manajemen Berdasarkan Nilai. Mc. Graw-Hill. New York. 